IZA DP No. 5606

Labour Market Institutions and Unemployment: Does Finance Matter?

Christophe Rault

Anne-Gaël Vaubourg

March 2011 


\title{
Labour Market Institutions and Unemployment: Does Finance Matter?
}

\author{
Christophe Rault \\ LEO-Université d'Orléans, \\ CESifo and IZA
}

\author{
Anne-Gaël Vaubourg \\ LEO-Université d'Orléans
}

\section{Discussion Paper No. 5606 \\ March 2011}

\author{
IZA \\ P.O. Box 7240 \\ 53072 Bonn \\ Germany \\ Phone: +49-228-3894-0 \\ Fax: +49-228-3894-180 \\ E-mail: iza@iza.org
}

\begin{abstract}
Any opinions expressed here are those of the author(s) and not those of IZA. Research published in this series may include views on policy, but the institute itself takes no institutional policy positions.

The Institute for the Study of Labor (IZA) in Bonn is a local and virtual international research center and a place of communication between science, politics and business. IZA is an independent nonprofit organization supported by Deutsche Post Foundation. The center is associated with the University of Bonn and offers a stimulating research environment through its international network, workshops and conferences, data service, project support, research visits and doctoral program. IZA engages in (i) original and internationally competitive research in all fields of labor economics, (ii) development of policy concepts, and (iii) dissemination of research results and concepts to the interested public.
\end{abstract}

IZA Discussion Papers often represent preliminary work and are circulated to encourage discussion. Citation of such a paper should account for its provisional character. A revised version may be available directly from the author. 
IZA Discussion Paper No. 5606

March 2011

\section{ABSTRACT}

\section{Labour Market Institutions and Unemployment: Does Finance Matter?*}

We explore whether finance influences the impact of labour market institutions on unemployment. Using a data set of 18 OECD countries over 1980-2004, we estimate a panel VectorAutoRegressive model. We check whether causalities from labour market variables to unemployment are affected by financial factors. In Belgium, Italy, Australia, Japan and Spain, accounting for financial indicators mitigates the benefits of labour market flexibilization or makes it harmful to employment. In Austria, Canada, Finland and Portugal, it reduces its detrimental impact or makes it beneficial. In Ireland and Netherlands, both effects prevail, depending on the labour market indicator used.

JEL Classification: E24, J23, P17

Keywords: unemployment, labour market, financial factors, institutional interactions, panel VAR

Corresponding author:

Christophe Rault

LEO

University of Orleans

Rue de Blois-B.P.6739

45067 Orléans Cedex 2

France

E-mail: christophe.rault@univ-orleans.fr

\footnotetext{
* We would like thank Donatella Gatti for providing us some of the data used in this paper as well as the participants of the 2011 Annual American Meeting of the Allied Social Science in Denver for very helpful comments on a previous and different version of this paper. Usual disclaimer applies.
} 


\section{Introduction}

The dramatic increase in unemployment rates due to the recent financial crisis in a large number of countries provides an additional clue that finance significantly affects employment performance. According to the new-Keynesian view, imperfections within the financial system (such as adjustment costs and information asymmetries) play a crucial role in firms' labour demand and in employment fluctuations. Greenwald \& Stiglitz (1993) and Arnold (2002) show that financial constraints induced by information asymmetries make firms' labour demand dependent on their balance-sheet position. As a consequence, employment fluctuates according to the financial pressures that firms face. These theoretical arguments are confirmed by firm-level econometric investigations. Sharpe (1994) documents that the sensitivity of American firms' labour demand to sales increases with their leverage ratio. Using a set of British firms, Nickell \& Wadhwani (1991) show that employment decreases with firms' leverage ratio and increases with their market capitalization while Nickell \& Nicolitsas (1999) establish that employment falls with the ratio of interest payment to cash-flow. Moreover, Caggese \& Cunat (2008) obtain that financial constraints influence firms' employment policy and the mix between permanent and temporary employment. Finally, Acemoglu (2001) examines how financial factors affect employment through their impact on firms' creation. Financial constraint harms employment because it hinders the emergence of new innovating firms, which create jobs. The author observes that, since the 60 's, the employment rates of firms dependent on external finance has been higher in Europe than in the United States, arguing that this is due to the stronger regulation of European financial systems 1 .

Financial factors are not the only drivers of unemployment. A large literature pays particular attention to labour market institutions as crucial determinants of employment performance. In Nickell (1997), Siebert (1997) and Layard \& Nickell (1999), strong labour market regulation, unemployment protection, wage taxation and union action are considered as factors of rigidity and unemployment2. Moreover, interactions among labour market arrangements are also shown to affect employment performance (Nickell, Nunziata, Ochel \& Quintini (2002), Nickell, Nunziata \& Ochel (2005) $)^{3}$.

These contributions on the determinants of unemployment have been recently enriched by fruitful developments which point out the existence of complex interactions between financial factors and labour market institutions. Beyond their effect on the design of the political system (Pagano \& Volpin (2005)), the nature of the legal framework (Ergrungor (2004), Botero et al. (2005)) or the distribution of financial wealth (Perroti \& Von Thadden (2006)), interactions between finance and labour market arrangements also influence job creation.

First, labour market devices are not neutral with respect to the way finance affects unemployment. While theoretical models by Rendon (2001) and Belke \& Fehn (2002) conclude that weaker

\footnotetext{
${ }^{1}$ For similar arguments concerning the impact of venture capital on firms' creation and employment, see Fechs \& Fuchs (2003) and Belke, Fehn \& Foster (2004).

${ }^{2}$ For a survey, see Arpaia \& Mourre (2005).

${ }^{3}$ In a similar vein, an abundant literature has been devoted to the interactions between labour market institutions and product market regulation (Blanchard \& Giavazzi (2003), Amable \& Gatti (2004), Nicoletti \& Scarpetta (2005), Amable \& Gatti (2006), Griffith, Harrison \& Macartney (2006), Berger \& Danninger (2007), Fiori, Nicoletti, Scarpetta \& Schiantarelli (2007), Kugler \& Pica (2008) and Amable, Demmou \& Gatti (2011)).
} 
labour market institutions mitigate the favourable effect of financial development on employment, Koskela \& Stenbacka (2004) obtain that they amplify the positive effect of intensified banking competition. Using a data set of 18 OECD countries between 1980 and 2004, Gatti, Rault \& Vaubourg (2011) propose an empirical investigation of these issues. They establish that increased market capitalization as well as decreased banking concentration reduce unemployment if the level of labour market regulation, union density and coordination in wage bargaining is low. Moreover, increasing intermediated credit and banking concentration is beneficial for employment when the degree of labour market regulation, union density and wage coordination is high.

Symmetrically, financial factors also influence the relationship between labour market arrangements and unemployment. On the one hand, Rendon (2001) obtains that financial development reduces the positive effect of labour market flexibilization on employment performance. On the other hand, Wasmer \& Weil (2004) find that fiercer competition in the credit market may exacerbate it. Conducting dynamic panel estimations, Gatti \& al. (2011) do not provide strong evidence supporting any of these theoretical predictions. But conclusions may be different in a countryspecific framework. For instance, finance may mitigate the effect of labour market flexibilization in some countries while it may exacerbate it in some others.

The goal of this paper is precisely to examine this issue by testing for Granger-causalities from labour market variables to unemployment in order to check whether these causalities are affected by financial variables for each country of the sample. We estimate a panel Vector AutoRegressive (VAR) model using the same data as Gatti \& al. (2011). We implement the panel-data approach of Kónya (2006), based on Seemingly Unrelated Regressions (SUR) system and Wald tests with country specific bootstrap critical values. In the specific framework we use, we allow for crosscountry correlation, without the need of pretesting for unit roots and cointegration (as in Phillips $(1995))$.

The paper is organized as follows. Section 2 presents the theoretical and empirical background of our study. Section 3 is devoted to the econometric investigation. Section 4 proposes some extensions to our analysis. Section 5 concludes.

\section{Theoretical and empirical background}

In this section, we present the theoretical and empirical background of our investigation.

\subsection{Theoretical literature}

Rendon (2001) provides a theoretical model where labour market flexibilization, through a reduction in adjustment costs (i.e., firing and hiring costs) fosters job creation. Financial development also promotes employment. As their access to external finance is improved, firms can more easily finance labour adjustment costs. Their hiring policy thus becomes less dependent on internal resources and they adjust their employment level more rapidly. Consequently, when the level of financial development is high, removing labour market adjustment costs has weak effect on employment since firing or hiring costs can be financed by security issuance. On the contrary, if financial development is low, labour market flexibilization becomes particularly effective since 
firms' ability to finance labour market adjustement costs is reduced.

Wasmer \& Weil (2004) concentrate on the effect of credit market concentration. Lower competition in labour and/or credit markets reduces markets' liquidity and agents' matching costs. Firms and workers match less easily on the labour market, as well as firms and banks on the credit market, yielding negative effects on employment. The model exhibits general-equilibrium interactions between credit and labour markets. More frictions in the credit market reduces the number of lenders such that it becomes more difficult for firms to match with a funder. This discourages the entry of firms, which in turn makes it less likely for workers to get a job. The detrimental effect of increased liquidity in the labour market is thus exacerbated by imperfections in the credit market.

The theoretical literature thus shows that finance is not neutral as regards the way labour market institutions affect employment performance. The goal of this paper is to check the empirical relevance of this view.

\subsection{Empirical literature}

Using annual firm-level data for 10 European countries over the period 1994-2000, Calcagnini, Giombini \& Saltari (2009) investigate how interactions between financial and labour market factors affect investment. Using the system Generalized Method of Moments (GMM) to estimate a dynamic panel-data model, in which the investment ratio is explained by the level of firm liquidity, the intensity of labour market regulation as well as a term that captures interactions between both variables. They find that the liquidity ratio has a positive impact on firms' investment while the degree of labour market regulation has a negative impact. More interestingly, the sign of the coefficient for the interaction between capital and labour market variables appears significant and negative. The authors then conclude that interactions among both financial and labour market imperfections contribute to lower investment. However, the paper does not provide any clear evidence as regards the way interactions between financial and labour market variables affect employment performance.

This issue of unemployment is explicitly explored by Gatti \& al. (2011). On a sample of 18 OECD countries over the period 1980-2004, they also resort to GMM techniques. The level of unemployment is explained by financial variables (stock market capitalization, intermediated credit and banking concentration), labour market factors (labour market regulation, union density and coordination in wage bargaining) as well as a term that captures interactions between both financial and labour market variables. They show that the impact of financial variables on unemployment strongly depends on the labour market context. More especially, increased market capitalization and reduced banking concentration curb unemployment if the level of labour market regulation, union density and coordination in wage bargaining is low. Moreover, raising intermediated credit and banking concentration promotes employment when the degree of labour market regulation, union density and wage coordination is high. However, the effect of labour variables turns out to be weakly affected by financial factors. Then, Gatti \& al. (2011) test for Granger-causalities from financial factors to unemployment for each country of their data set. Their panel VAR approach confirms their GMM results. No causality appears from financial variables to unemployment when the labour market context in not taken into account. However, when labour market devices are 
accounted for, the paper documents significant causalities from financial variables to unemployment in many countries of the data set. Moreover, the signs of causalities are mainly consistent with GMM results. But the authors do not investigate Granger-causalities from labour market institutions to unemployment nor whether they could be affected by financial indicators.

The goal of our paper is to fill this gap. Panel VAR estimations should allow us to refine the findings obtained by Gatti \& al. (2011) using GMM techniques: while financial factors do not influence the relationship between labour market institutions and unemployment from an aggregate point of view, they may have an impact when adopting a country-specific approach.

\section{Econometric investigation}

This section is devoted to the econometric analysis. The first subsection focuses on data and the econometric methodology while the second subsection presents our results.

\subsection{Data and econometric methodology}

Following Gatti \& al. (2011), we use a panel that includes annual data for 18 OECD countries (Australia, Austria, Belgium, Canada, Denmark, Finland, France, Germany, Ireland, Italy, Japan, Netherlands, Norway, Portugal, Spain, Sweden, United Kingdom and United States) which covers the period 1980-2004.

To conduct our panel VAR analysis, we consider three categories of variables. First, $U$ is the standardized rate of unemployment taken from the OECD.

Second, $L A B$ is a set of five variables accounting for labour market institutions. $L M R$ is the measure of employment protection legislation built by Amable, Demmou \& Gatti (2011) 4 . It is a time-series variable between 0 (for the lowest level of employment protection) to 3 (for the highest level of protection). COORD evaluates the degree of coordination in wage bargaining. Taken from Nickell \& al. (2005), this variable ranges from 0 to 3 with higher scores corresponding to higher coordination. UNION is the degree of union density, calculated by the OECD as the proportion of union members among workers. In Section 4, we extent our analysis to two additional $L A B$ variables, both provided by the OECD. The first one, denoted $W E D G E$, stands for the tax wedge while the second one, REPLACE, measures the replacement rate for unemployment benefit respectively. The higher these five indicators, the tighter labour market institutions.

Finally, FIN denotes a set of three financial indicators, all taken from the Demircüç-Kunt \& Levine (2001) data set. The two first variables account for financial development. CAPI is a ratio of stock market capitalization to GDP. CREDIT is a ratio of intermediated credit, measured by the claims to the private sector by financial intermediaries (deposit money banks, insurance companies, private pensions, pooled investment schemes and development banks) to GDP. The

\footnotetext{
${ }^{4}$ This time-series indicator is based on EPL (Employment Protection Legislation) scores obtained from Nickell $\&$ al. (2005) as well as on measures of structural reforms provided by the FRDB Database (the number of reforms passed each year in each country, whether they are directed towards more flexibility as well as whether they apply to all, or a large majority of professional categories, contract typologies etc).
} 
third indicator, $C O N C$, measures the degree of concentration of the banking sector. It is defined as the ratio of the three largest banks' asset to total banking sector assets. Note that this ratio is only available over the period 1990-2004.

The list of these variables is reported in Table A.1 in Appendix. Table A.2, also included in Appendix, provides summary statistics for each of them.

Our approach consists in testing for Granger-causalities from labour market variables $(L A B)$ to unemployment $(U)$. Our goal is to explore whether (and how) these causalities are affected by financial variables $(F I N)$ for each country of our data set. To do this, we use the recent bootstrap panel causality test developed by Kónya (2006), which is based on the following bivariate (here composed of unemployment, $U$ and one labour market indicator, $L A B$ ) or trivariate (here $U, L A B$ and one financial indicator $F I N$ ) finite-order vector autoregressive models, with the variables taken in level:

$$
\left\{\begin{array}{l}
U_{i, t}=\alpha_{1, i}+\sum_{j=1}^{p_{1}} \beta_{1, i, j} U_{i, t-j}+\sum_{j=1}^{p_{2}} \gamma_{1, i, j} L A B_{i, t-j}+\varepsilon_{1, i, t} \quad t=1, \ldots, T \quad i=1, \ldots, N \quad(1 a) \\
L A B_{i t}=\alpha_{2, i}+\sum_{j=1}^{p_{1}} \beta_{2, i, j} U_{i, t-j}+\sum_{j=1}^{p_{2}} \gamma_{2, i, j} L A B_{i, t-j}+\varepsilon_{2, i, t} \quad t=1, \ldots, T \quad i=1, \ldots, N
\end{array}\right.
$$

and

$$
\left\{\begin{array}{l}
U_{i, t}=\alpha_{1, i}+\sum_{j=1}^{p_{1}} \beta_{1, i, j} U_{i, t-j}+\sum_{j=1}^{p_{2}} \gamma_{1, i, j} L A B_{i, t-j}+\sum_{j=1}^{p_{3}} \eta_{1, i, j} F I N_{i, t-j}+\varepsilon_{1, i, t} \quad t=1, \ldots, T \quad i=1, \ldots, N \quad(2 a) \\
L A B_{i, t}=\alpha_{2, i}+\sum_{j=1}^{p_{1}} \beta_{2, i, j} U_{i, t-j}+\sum_{j=1}^{p_{2}} \gamma_{2, i, j} L A B_{i, t-j}+\sum_{j=1}^{p_{3}} \eta_{2, i, j} F I N_{i, t-j}+\varepsilon_{2, i, t} \quad t=1, \ldots, T \quad i=1, \ldots, N
\end{array}\right.
$$

, where the index $i(i=1, \ldots, N)$ is the country, the index $t(t=1, \ldots, T)$ the period, $j$ the lag, and $p_{1 i}, p_{2 i}, p_{3 i}$ the longest lags in the system. The error terms $\varepsilon_{1, i, t}$, and $\varepsilon_{2, i, t}$ are supposed to be white-noise and may be correlated with each other for a given country.

Systems (1) and (2) are estimated by the Seemingly Unrelated Regressions (SUR) procedure (since possible links may exist among individual regressions via contemporaneous correlation within equations (1a) and (1b) of system (1); and within equations (2a) and (2b) of system (2)). Then Wald tests for Granger-causality are performed with country specific bootstrap critical values generated by simulations.

With respect to system (1) for instance, in country $i$ there exists a one-way Granger-causality running from $L A B$ to $U$ if in the first equation, not all $\gamma_{1, i}$ are zero but in the second, all $\beta_{2, i}$ are zero; there is a one-way Granger-causality from $U$ to $L A B$ if in the first equation, all are $\gamma_{1, i}$ zero but in the second, not all $\beta_{2, i}$ are zero; there is a two-way Granger-causality between $U$ to $L A B$ if neither all $\gamma_{1, i}$ nor all $\beta_{2, i}$ are zero; and there is no Granger-causality between $U$ to $L A B$ if all $\gamma_{1, i}$ and $\beta_{2, i}$ are zerq ${ }^{5}$.

\footnotetext{
${ }^{5}$ As stressed by Kónya (2006), this definition implies causality for one period ahead.
} 
This procedure has several advantages. Firstly, it does not assume that the panel is homogeneous, so that it allows to test for Granger-causality on each individual panel member separately. However, since contemporaneous correlation is allowed across countries, it makes it possible to exploit the extra information provided by the panel data setting and therefore country-specific bootstrap critical values are generated. Secondly, this panel approach generalises the methodology developed by Phillips (1995) $]^{6}$ that tests for non-causality in level VARs. In a time-series context, it does not require pretesting for unit roots and cointegration, though it still requires the specification of the lag structure (which is determined here using the Akaike Information Criterion (AIC) and the Schwarz Information Criterion (SIC)). This is an important feature since unit-root and cointegration tests generally suffer from low power, and different tests often lead to contradictory outcomes. Thirdly, this panel Granger-causality approach allows to detect for how many and for which members of the panel there exists a one-way Granger-causality, a two-way Granger-causality or no Granger-causality.

Finally, our econometric approach can be summarised as follows. For each country of our sample we first estimate three bivariate panel VAR models, each including one labour market variable (labour market regulation, union density and wage coordination successively) and unemployment. We then estimate nine trivariate panel VAR models, each including one labour market variable, one financial variable (market capitalization, intermediated credit or concentration) and unemployment. Comparing bivariate and trivariate estimations will allow us to check whether introducing a financial variable in the VAR model affects the causality (or the absence of causality) from labour market factors to unemployment.

\subsection{Results}

Results of panel VAR estimates are reported in Tables 1, 2 and 3. Table 1 summarizes Grangercausality tests from labour market regulation $(L M R E G)$ to unemployment while Tables 2 and 3 relate to Granger-causalities from union density $(U N I O N)$ to unemployment and from wage coordination $(C O O R D)$ to unemployment respectively. In each table, Part A reports the results for the bivariate VAR model estimations while Part B, Part C and Part D present the results for the trivariate VAR model estimations, including stock market capitalization $(C A P I)$, intermediated credit $(C R E D I T)$ and banking concentration $(C O N C)$ respectively.

\footnotetext{
${ }^{6} \mathrm{As}$ it is now well known, testing for non-causality is addressed in a time-series setting, in particular by Phillips (1995) in the context of a level VAR estimated using the Fully Modified (FM) estimator, as well as by Toda \& Yamamoto (1995) who suggest augmenting the VAR by the maximal order of integration for the process being examined. The former method provides some very interesting results as far as asymptotic inference is concerned. The most important one is that statistical inference in this framework can be conducted by means of standard asymptotics. In this case, no unit root limit theory is required. Normal and mixed normal limit theory is applied to the stationary and non-stationary components of the VAR respectively. This implies that optimal inference in level VARs and Wald test for non-causality can be obtained without prior knowledge of the number of unit roots or the order of cointegration rank in the system, and without the use of reduced rank Johansen-type regressions (which are subject to pretesting bias, since tests for cointegration ranks are extremely sensitive to the values of the nuisance parameters). The approach by Toda \& Yamamoto (1995) also results in a standard Wald statistic for non-causality restrictions, although it requires some pretesting for determining the lag length of the VAR.
} 
Tables 1 to 3 reveal interesting facts. To start with, it is worth noting that, except in a very few countries, there exists no robust causality from labour market variables to unemployment in bivariate models (Part A of Tables 1 to 3). This is in line with Amable \& al. (2011) and Gatti \& al. (2011). This is also consistent with Baker, Glyn, Howell \& Schmitt (2004), who moderate the view that labour market institutions, notably labour protection and union density, has played a crucial role as regards labour market performance in OECD countries since the 80ies. However, when the estimated model contains one financial variable (Parts B, C and D of Tables 1 to 3), causalities between labour market factors and unemployment arise in many countries. This lends some support to the view that finance crucially influences the impact of labour market arrangements on unemployment. Moreover, comparing Tables 1, 2 and 3 suggests that financial factors particularly matter as regards the impact of wage coordination on employment.

Let us now analyze the coefficients reported in Tables 1 to 3 in detail. In a first group of countries, accounting for financial variables mitigates the positive impact of increased labour market flexibility on employment 7 . In Ireland, weaker labour market regulation decreases unemployment (Part A of Table 1) but this relationship vanishes when the level of stock market capitalization or the degree of banking concentration is introduced in the estimation (Parts B and D of Table 1). In Belgium, weaker wage coordination also reduces unemployment (Part A of Table 3) but this beneficial effect does no arise anymore when stock market capitalization and intermediated credit are accounted for (Parts B and $\mathrm{C}$ of Table 3).

In some countries, accounting for financial factors even makes labour market flexibilization harmful to unemployment. This observation is in line with a few papers which, in opposition to most of the literature on labour market institutions, point out the benefits of labour protection (Bentolila \& Bertola (1990), Fella (2004)). Part C of Table 1 shows that in Ireland, a decline in labour market protection turns out to bring negative effects on employment due to the introduction of intermediated credit in the model. In Italy, introducing the level of market capitalization in the estimation also makes labour market flexibilization harmful for employment (Part B of Table 1) while it has no effect in the bivariate model (Part A of Table 1). The same phenomenon is observed in Netherlands as regards the effect of weaker union density (Part A and Part B of Table 2). Moreover, Parts A, B and C of Table 3 report that in Australia, Japan and Spain, less coordinated wage bargaining damages employment performance when stock market capitalisation or intermediated credit are introduced in the model. This harmful impact of weaker coordination is documented in the empirical literature (Nickell (1997), Nickell \& al. (2002)). It is also in line with the theoretical argument that coordination works as a wage moderation device (Calmsfors \& Driffill (1988)): when the labour market becomes less coordinated, this moderation effect is weakened and employment is reduced. Finally, in Finland, when banking concentration is introduced in the estimation, weaker labour market regulation increases unemployment (Part D of Table 1) while it has no significant impact in the bivariate model (Part A of Table 1).

In a second set of countries, the introduction of financial variables results in a positive effect

\footnotetext{
${ }^{7}$ Note that our estimates do not allow to check whether the mitigation effect results from a rise or from a decline in financial development or banking concentration.
} 
of labour market flexibilisation on employment. In Canada and Portugal, decreased union density has no effect on unemployment (Part A of Table 2) but it turns out to be favourable to employment when one accounts for the level of stock market capitalization or intermediated credit (Parts B and $\mathrm{C}$ of Table 2). Similarly, in Netherlands, reduced wage coordination does not affect employment (Part A of Table 3) but when taking intermediated credit into account, it contributes to curb unemployment (Part C of Table 3). Finally, Parts D of Table 2 and Table 3 report that in Sweden, decreased union density and reduced wage coordination respectively are made beneficial to employment when taking into account the level of concentration in the banking sector 8 . Combined with the result obtained above for Finland, this suggests that in Scandinavian countries, the structure of the banking market plays a particularly important role as regards interactions with labour market institutions?

Moreover, there exist some countries in which the introduction of financial variables does not amplify the positive effect of labour market flexibilisation on employment but, at least, contributes to curb its harmful effects. This is the case for Austria, in which reduced union density and wage coordination have no effect when market capitalization and intermediated credit are introduced in the estimation (Parts $\mathrm{B}$ and $\mathrm{C}$ of Tables 2 and 3 respectively) while they have a negative impact on employment in the bivariate model (Part A of Tables 2 and 3 respectively). Similarly, in Ireland, the detrimental effect of reduced wage coordination on employment (Part A of Table 3) disappears due to the introduction of stock market capitalization (Part B of Table 3) and intermediated credit (Part C of Table 3)

Taken together, these findings corroborate the idea that finance significantly affects the relationship between labour market institutions and unemployment. In some countries, financial factors mitigate the favourable impact of increased labour market flexibility or even make it harmful to employment. In some others, they make labour market flexibilization beneficial to employment or curbs its unfavourable effect. This diversity among countries may explain why aggregate estimations by Gatti \& al. (2011) do not provide any clear-cut support to the theoretical argument that finance affects the relationship between labour market variables and unemployment.

\footnotetext{
${ }^{8}$ It is also true that reduced wage coordination becomes harmful to employment when introducing intermediated credit in the estimation (Part $\mathrm{C}$ of Table 3). But this effect appears less significant than the beneficial effect of introducing banking concentration.

${ }^{9}$ The paper by Koskela \& Stenbacka (2004) provides an interesting example of the emphasis put on interactions between labour market institutions and banking concentration in Scandinavian countries.

${ }^{10}$ The detrimental effect of reduced wage coordination in the case of Ireland is in line with Baker et al. (2004) who stress the role played by high wage coordination in the Irish employment success since the 1980s.
} 


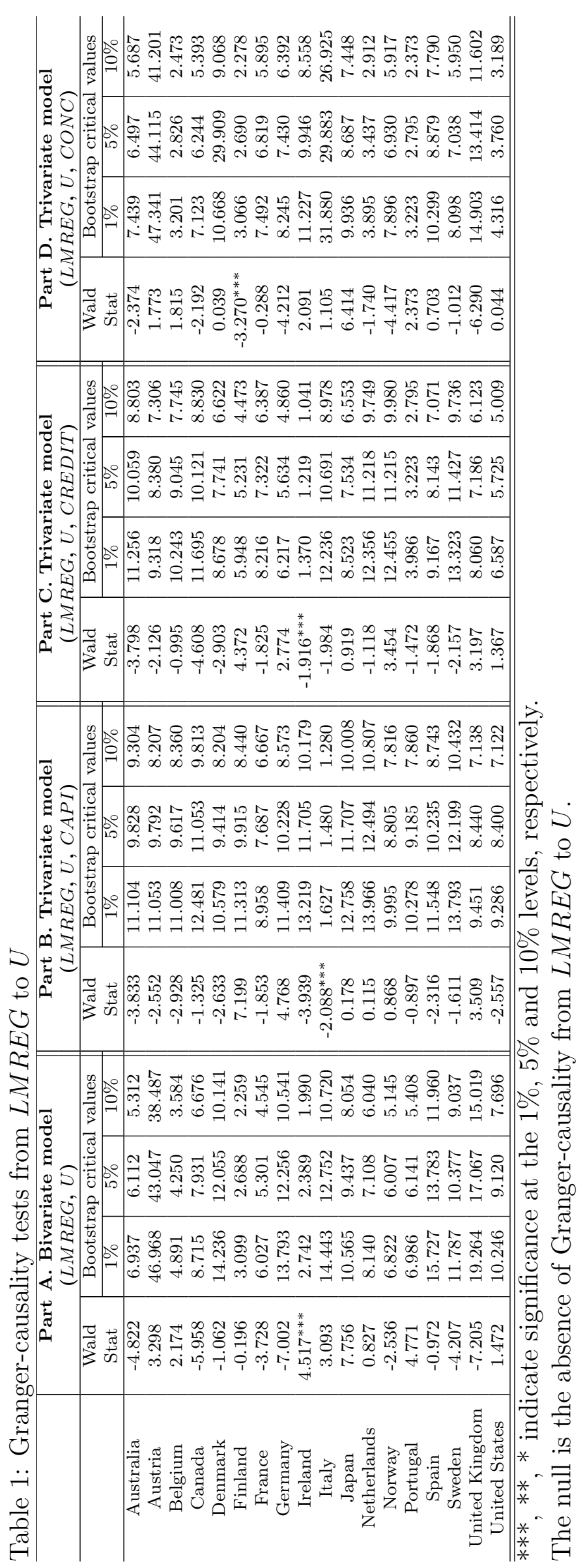




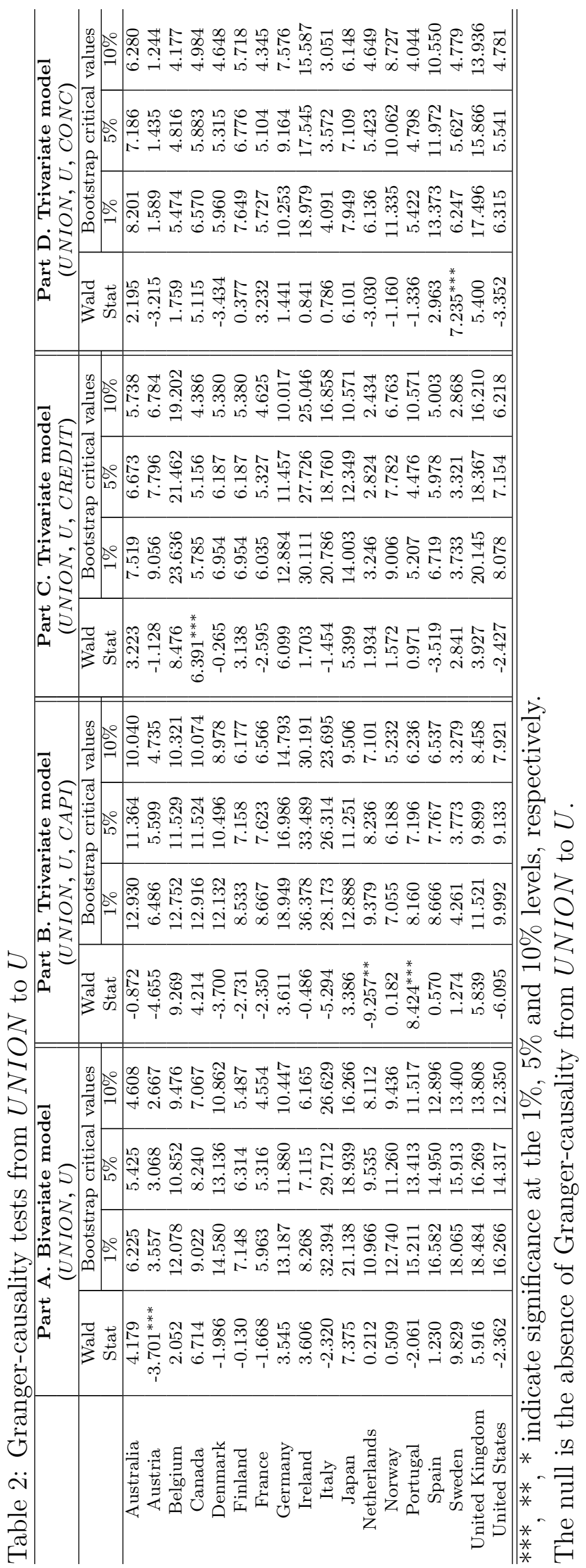




\section{Extensions}

In this section, we propose two extensions to our analysis. Inspired by the literature on labour market institutions (Nickell, Nunziata \& Ochel (2005), Nickell (1997), Baccaro \& Rei (2007) and Amable \& al. (2011)), we consider the tax wedge (WEDGE) as well as the gross replacement rate on unemployment ( $R E P L A C E)$ as alternative labour market indicators. We thus estimate two bivariate panel VAR models, including the tax wedge or the gross replacement rate and the unemployment rate. We then estimate six trivariate panel VAR models, each containing the tax wedge or the gross replacement, one financial variable (market capitalization, intermediated credit or banking concentration) and the unemployment rate.

Granger-causality tests from the tax wedge to unemployment and from the replacement rate to unemployment are reported in Tables 4 and 5 respectively. As in Tables 1 to 3, Part A presents the results for the bivariate VAR model estimations while Part B, Part $\mathrm{C}$ and Part D provide the results for the trivariate VAR model estimations with stock market capitalization $(C A P I)$, intermediated credit $(C R E D I T)$ and banking concentration $(C O N C)$ respectively.

Results reported in Tables 4 and 5 indicate that in most countries of our data set, there exists no Granger-causality from tax wedge and from the replacement rate to unemployment. This observation is consistent with Amable \& al. (2011), and Gatti \& al. (2011)). This is the case

in the bivariate model (Part A of Tables 4 and 5). But - and this sharply contrasts with the findings obtained in Section 3 -, this also holds when financial factors are taking into account in the estimation (Parts B to D of Tables 4 and 5).

However, three exceptions can be pointed out. First, Table 4 reveals that, in Ireland, the favourable effect of decreased tax wedge on unemployment (Part A) disappears when accounting for stock market capitalization (Part B), intermediated credit (Part C) or banking concentration (Part D). Hence, in this case, financial factors mitigate the positive effects of stronger labour market flexibility. Second, in Germany, reduced tax wedge has no effect on unemployment in the bivariate model (Part A of Table 4) while it contributes to raise unemployment (Part D of Table 4) when accounting for banking concentration. Finance thus makes labour market flexibilization unfavourable to employment. Finally, in Italy, while there exists no causality from the replacement rate to unemployment in the bivariate model (Part A of Table 5), a lower replacement rate enhances employment when stock market capitalization is introduced in the estimation (Part B of Table 5). Hence, in this country, financial factors make stronger labour market flexibility beneficial for employment.

Finally, although they exhibit some interesting results, the estimations presented in this section provide no striking evidence that finance influences the impact of tax wedge or replacement rate on unemployment. 


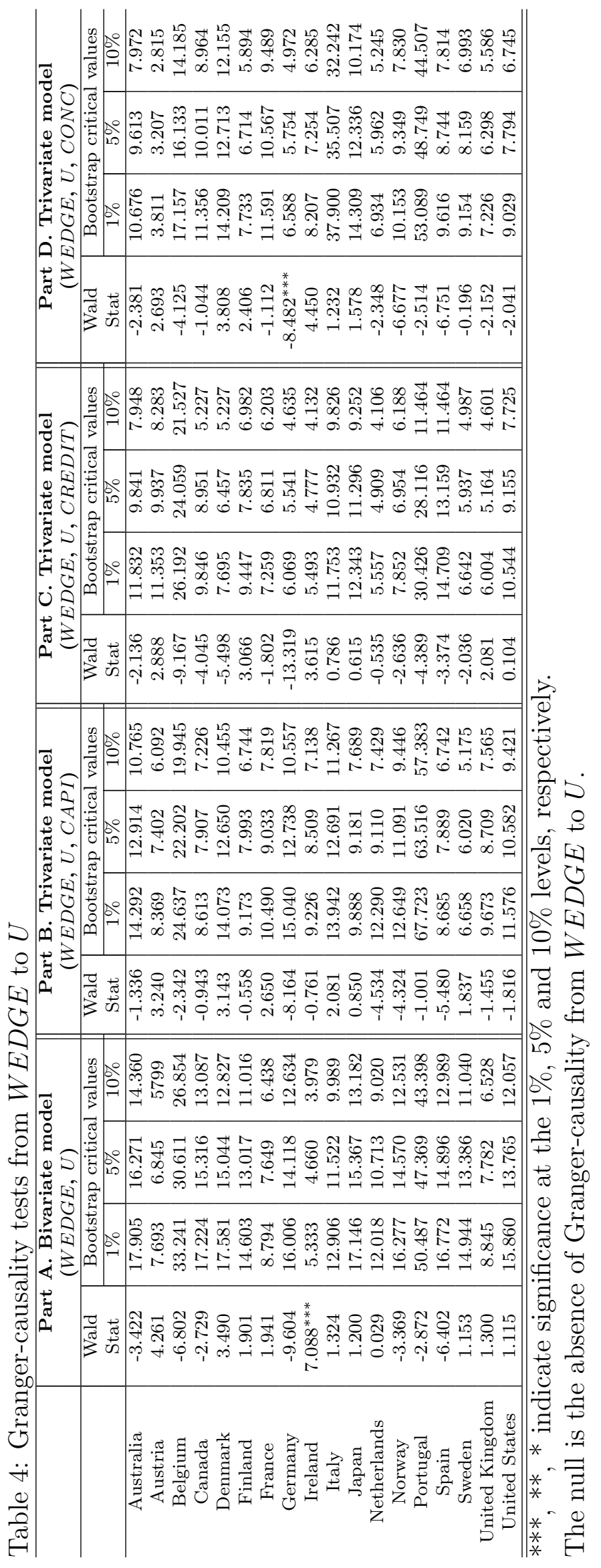




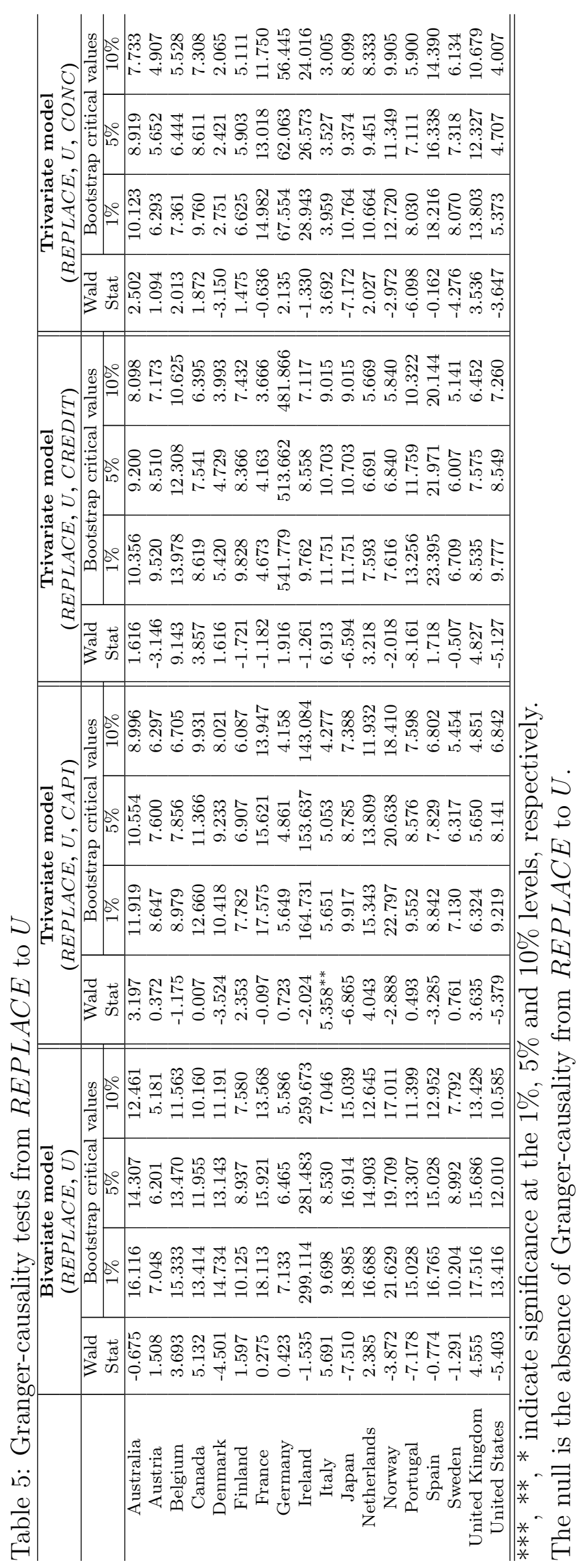




\section{Conclusion}

The aim of this empirical contribution was to explore whether financial factors (stock market capitalization, intermediated credit and banking concentration) influence the effect of labour market institutions (labour market regulation, union density, degree of wage bargaining, tax wedge and replacement rate) on unemployment. Using a data set of 18 OECD countries over the period 19802004, we estimated a panel VAR model. We tested for Granger-causalities from labour market variables to unemployment following the panel-data approach of Kónya (2006), which is based on SUR systems and Wald tests with country specific bootstrap critical values. This allowed us to check, for each country of our sample, in what extent causalities from labour market arrangements to unemployment are affected by financial variables.

Our investigation provides interesting evidence that finance influences the relationship between labour market arrangements and unemployment in a complex way. It also highlights the great diversity of situations among countries. It is shown that in Australia, Belgium, Finland, Italy, Japan and Spain, accounting for financial arrangements mitigates the favourable impact of labour market flexibilization or even makes it harmful to employment. In Austria, Canada, Sweden and Portugal, it reduces its harmful impact on employment or makes its beneficial. In Ireland and Netherlands, both effects take place, depending on the labour market indicator used. When one considers labour market protection (in Ireland) or union density (in Netherlands), the former effect prevails. Conversely, in both countries, when one considers the degree of coordination in wage bargaining, the latter effect is at play. Another finding is that, in most countries of the data set, there exists no significant causality from replacement rate or tax wedge to unemployment, even when financial variables are introduced in the estimation. However, Ireland, where reduced tax wedge is shown to mitigate the benefits of stronger labour market flexibility, offers an interesting exception to this observation. Taken with our other results, it suggests that Irish employment is particularly sensitive to interactions between labour market institutions and financial factors.

Our paper globally advocates care in analysing the effectiveness of financial policies. Above their direct effect on employment, already documented in earlier literature, they also affect employment performance indirectly, through their interactions with labour market institutions.

In conclusion, our investigation opens up a rich research agenda. It is worth noting that theoretical papers on interactions between labour market and financial arrangements mainly refer to the view that labour market deregulation promotes employment. However, in line with a few earlier papers, our empirical results show that it can also have detrimental effects. The issue of interactions between financial and labour market devices thus appears particularly complex: finance does not only affect the intensity of the relationship between labour market arrangements and unemployment but may also modify its sign. This empirical observation undoubtedly deserves to be theoretically formalised and investigated more deeply.

\section{References}

Acemoglu, D. (2001), 'Credit market imperfections and persistent unemployment', European Economic Review 45, 665-679. 
Amable, B. \& Gatti, D. (2004), 'Product market competition, job security and aggregate unemployment', Oxford Economic Papers 56, 667-686.

Amable, B. \& Gatti, D. (2006), 'Labour and product market reforms: Questioning policy complementarity', Industrial and Corporate Change 15, 101-122.

Amable, B., Demmou, L. \& Gatti, D. (2011), 'The effect of employment protection and product market regulation on labour market performance: substitution or complementarity?', Applied Economics, 43, 449-464.

Arnold, L. (2002), 'Financial market imperfections, labour market imperfections and business cycles', Scandinavian Journal of Economics 104, 105-124.

Arpaia, A. \& Mourre, G. (2005), 'Labour market institutions and labour market performance: A survey of the literature', European Commission Economic Paper 238.

Baccaro, L. \& Rei, D. (2007), 'Institutional determinants of unemployment in OECD countries: A time-series cross-section analysis (1960-1998)', International Organization 61, 527-569.

Baker, D., Glyn, A., Howell D. \& Schmitt J. (2004), 'Labour market institutions and unemployment: a critical assessment of cross-country evidence', in D. Howell (ed.), Fighting unemployment: the limits of free market orthodoxy, Oxford University Press, Oxford.

Belke, A. \& Fehn, R. (2002), 'Institutions and structural unemployment: Do capital market imperfections matter?',Ifo Studien - Zeitschrift für empirische Wirtschaftsforschung 48, 405451. Discussion Paper 190/2000, Departement of Economics, University of Hohenheim.

Belke, A., Fehn, R. \& Foster, N. (2004), 'Venture capital investment and labour market performance: A panel data analysis', Problems and Perspectives in Management, special issue on innovation management, 5-19. CESInfo Working Paper 562.

Belot, M. \& Ours, J.-C. V. (2001), 'Unemployment and labour market institutions: An empirical analysis', Journal of the Japanese and International Economies 15, 403-418.

Bentolila, S. \& Bertola, G. (1990), 'Firing costs and labour demand: How bad is eurosclerosis?', Review of Economic Studies 57, 381-402.

Berger, H. \& Danninger, S. (2007), 'The employment effects of labour and product markets deregulation and their implications for structural reform', IMF Staff Paper 54, 591-619.

Blanchard, O. \& Giavazzi, F. (2003), 'Macroeconomic effects of regulation and deregulation in goods and labour markets', Quarterly Journal of Economics 118, 879-907.

Botero, J., Djankov, S., La Porta, R., López-de-Silanes, F. and Shleifer, A. (2005) 'The regulation of labour', Quarterly Journal of Economics, 119, 1339-1382.

Caggese, A. \& Cunat, V. (2008), 'Financing constraint and fixed-term employment contract', Economic Journal, 118, 2013-2046. 
Calcagnini, G., Giombini, G. \& Saltari, E. (2009), 'Financial and labor market imperfections and investment', Economics Letters 109, 22-26.

Calmsfors, L. \& Driffill, J. (1988), 'Bargaining structure, corporatism and macroeconomic performance', Economic Policy 6, 14-61.

Demircüç-Kunt, A. \& Levine, R. (2001), Financial structures and economic growth: A cross country-comparison of banks, markets and development, MIT Press.

Ergrungor, O. (2004), 'Market- vs. bank-based financial systems: Do rights and regulations really matter?', Journal of Banking and Finance 28, 2869-2887.

Fechs, R. \& Fuchs, T. (2003), 'Capital market institutions and venture capital: Do they affect unemployment and labour demand?', CESIfo Working Paper 898.

Fella, G. (2004), 'Efficiency wage and efficient redundancy pay', European Economic Review 44, 1473-14780.

Fiori, G., Nicoletti, G., Scarpetta, S. \& Schiantarelli, F. (2007), 'Employment outcomes and the interaction between product and labour market deregulation: Are they substitutes or complements?', IZA Discussion Paper 2770.

Gatti, D., Rault, C. \& Vaubourg A.-G. (2011), 'Unemployment and finance: how do financial and labour market factors interact?', CESIfo Working Paper 2901.

Greenwald, B. \& Stiglitz, J. (1993), 'Financial market imperfection and business cycles', Quarterly Journal of Economics 108, 74-114.

Griffith, R., Harrison, R. \& Macartney, G. (2006), 'Product market reforms, labour market institutions and unemployment', Economic Journal 117, 142-166. Papers 2006/06.

Kónya, L. (2006), 'Exports and growth: Granger-causality analysis on OECD countries with a panel approach', Economic Modelling 23, 978-992.

Koskela, E. \& Stenbacka, R. (2004), 'Profit sharing, credit market imperfections and equilibrium unemployment', Scandinavian Journal of Economics 106, 677-701.

Kugler, A. \& Pica, G. (2008), 'Effects of employment protection and product market regulations on job and workers flows: Evidence from the 1990 Italian reform', Labour Economics 15, 78-95.

Layard R. and Nickell S. (1999), 'Labour market institutions and economic performance', in: O. Ashenfelter \& D. Card (ed.), Handbook of labour economics, Elsevier.

Nickell, S. (1997), 'Unemployment and labour market rigidities: Europe versus North America', Journal of Economic Perspectives 11, 55-74.

Nickell, S. \& Nicolitsas, D. (1999), 'How does financial pressure affect firms?', European Economic Review 43, 1435-1456. 
Nickell, S. \& Wadhwani, S. (1991), 'Employment determination in British industry: Investigation using micro-data', Review of Economic Studies 58, 955-969.

Nickell, S., Nunziata, L. \& Ochel, W. (2005), 'Unemployment in the OECD. What do we know?', Economic Journal 115, 1-27.

Nickell, S., Nunziata, L., Ochel, W. \& Quintini, G. (2002), Beveridge Curve, Unemployment and Wages in the OECD from the 60s to the 90s, in: P. Aghion , R. Frydman, J. Stiglitz and J. Woodford (ed.), Knowledge, information and expectations in modern macroeconomics: In Honor of E. Phelps, Princeton University Press.

Nicoletti, G. \& Scarpetta, S. (2005), 'Product market reforms and employment in OECD countries', OECD Economics Department Working Paper 472.

Pagano, M. \& Volpin, P. (2005), 'The political economy of corporate governance', American Economic Review, 95, 4, 1005-1030.

Perroti, E. \& Thadden, E.-L. (2006), 'The political economy of corporate control', Journal of Political Economy 114, 145-175.

Phillips, P. (1995), 'Fully modified least squares and vector autoregression', Econometrica 63, 1023-1078.

Rendon, S. (2001), 'Job creation under liquidity constraints: The Spanish case', Banco de Espana Working Paper 0101.

Sharpe, S. (1994), 'Financial market imperfections, firm leverage and the cyclicity of employment', American Economic Review 84, 1060-1074.

Siebert, H. (1997), 'Labour market rigidities: At the root of unemployment in Europe', Journal of Economic Perspectives 11, 37-54.

Toda, H. \& Yamamoto, T. (1995), 'Statistical inference in vector autoregressions with possibly integrated processes', Journal of Econometrics, 66, 225-250.

Wasmer, E. \& Weil, P. (2004), 'The macroconomics of labour and credit market imperfections', American Economic Review 94, 944-963. 


\section{Appendix}

Table A.1: List of variables

\begin{tabular}{l|l}
\hline \hline$U$ & Standardized rate of unemployment (OECD) \\
\hline$L M R E G(0-3)$ & $\begin{array}{l}\text { Labour market regulation indicator, Amable et al. (2011) from Nickell et al. (2005) and the FRDB } \\
\text { database }\end{array}$ \\
UNION & Number of union members as percent of total workers, OECD \\
$C O O R D(0-3)$ & Index of coordination in wage bargaining, Nickell \& al. (2005) \\
$W E D G E$ & Tax wedge, OECD \\
$R E P L A C E$ & Net replacement rate on unemployment benefit, OECD \\
\hline$C A P I$ & Stock market capitalization to GDP, Demircüc-Kunt \& Levine (2001) \\
$C R E D I T$ & Claims to the private sector by financial intermediaries to GDP, Demircüç-Kunt \& Levine $(2001)$ \\
$C O N C$ & Three largest banks' asset to total banking sector assets, Demircüç-Kunt \& Levine (2001) \\
\hline \hline
\end{tabular}

Table A.2: Statistical summary for variables (1980-2004)

\begin{tabular}{l|c|c|c|c|c}
\hline \hline Variables & Mean & Standard deviation & Max & Min & Nonmissing obs. \\
\hline \hline U & 7.447 & 3.504 & 19.5 & 1.5 & 441 \\
LMREG & 1.140 & 0.558 & 0.558 & 0.1 & 410 \\
UNION & 41.996 & 21.068 & 87.4 & 7.4 & 378 \\
COORD & 2.051 & 0.578 & 3 & 1 & 403 \\
WEDGE & 28.693 & 8.081 & 46.962 & 12.944 & 430 \\
REPLACE & 0.356 & 1.312 & 28 & 0 & 430 \\
CAPI & 0.492 & 0.404 & 2.7 & 0.003 & 432 \\
CREDIT & 0.878 & 0.378 & 2.168 & 0.220 & 450 \\
CONC & 0.678 & 0.203 & 1 & 0.226 & 450 \\
\hline \hline
\end{tabular}

